Please do not remove this page

RMIT

UNIVERSITY

\title{
The raising of corporate sponsorship: a behavioural study
}

Brennan, Linda-Marie; Binney, Wayne; Brady, Erica

https://researchrepository.rmit.edu.au/esploro/outputs/9921858549401341/filesAndLinks?institution=61RMIT_INST\&index=null

Brennan, L.-M., Binney, W., \& Brady, E. (2012). The raising of corporate sponsorship: a behavioural study. Journal of Nonprofit and Public Sector Marketing, 24(3), 222-237.

https://doi.org/10.1080/10495142.2012.705181

Document Version: Accepted Manuscript

Published Version: https://doi.org/10.1080/10495142.2012.705181

Repository homepage: https://researchrepository.rmit.edu.au

Copyright (C) 2012 Crown copyright

Downloaded On 2023/04/26 16:13:07 +1000

Please do not remove this page 
Thank you for downloading this document from the RMIT Research Repository.

The RMIT Research Repository is an open access database showcasing the research outputs of RMIT University researchers.

RMIT Research Repository: http://researchbank.rmit.edu.au/

\section{Citation:}

Brennan, L, Binney, W and Brady, E 2012, 'The raising of corporate sponsorship: a behavioural study', Journal of Nonprofit \& Public Sector Marketing, vol. 24, no. 3, pp. 222-237.

See this record in the RMIT Research Repository at:

http://researchbank.rmit.edu.au/view/rmit:16964

Version: Accepted Manuscript

Copyright Statement: (c) 2012 Crown copyright

Link to Published Version:

http://dx.doi.org/10.1080/10495142.2012.705181 


\section{The raising of corporate sponsorship: a behavioural study}

Authors:

Linda Brennan ${ }^{\text {a }}$

Wayne Binney *b

Erica Brady c

a Centre of Commerce and Management, RMIT Vietnam; School of Media and Communication, RMIT University, GPO Box 2476 MELBOURNE Vic. 3001 Email: Linda.Brennan@rmit.edu.vn Tel: + 84837761402

b Deakin Graduate School of Business, Faculty of Business and Law, 70 Elgar Rd, Burwood, Victoria.3125 Australia. Email: Wayne.Binney@deakin.edu.au Tel. +61 392445540

${ }^{c}$ Department of Marketing, Monash University Sir John Monash Drive Caulfield East Vic. 3145 Email: Erica.Brady@monash.edu Tel: + 61399032456

* Corresponding author 


\title{
The raising of corporate sponsorship: a behavioural study
}

\begin{abstract}
Research was conducted in order to define a 'buyer behaviour' process for the 'purchase' of sponsorship at a corporate level. A series of interviews was carried out with a number of organizations that are currently involved in sponsorship of varying kinds. A consideration was made to include a balance of sponsorship types; small and large, as well as Arts, Sport and Events although no attempt was made to identify how the process differs across sponsorship type. Our results show that while sponsorship and fundraising are flipsides of the same coin from the non-profit sponsorship seeker's perspective, the sponsorship provider sees the act of sponsorship as a commercial profit-making venture. This is a conundrum that has wide reaching consequences for the sector.
\end{abstract}

\section{Introduction}

Nonprofit organizations are now almost equally relying on funds from sponsorship and philanthropic donations (IEG 2011). While fundraising from individuals was a primary concern for nonprofits, organizations are increasingly turning to seeking corporate sponsors in order to firstly, stabilise cash flows (Peloza and Hassay 2008) and secondly, maximize the effectiveness of their fundraising efforts (Runte, Basil et al. 2009). However, we argue that non-profit organizations may be misdirected in their fundraising efforts because they perceive that sponsorship and philanthropy are inter-related concepts (Mullen 1999). We propose that nonprofits consider the business implications of sponsorship and change their fundraising strategies to meet the business needs of their potential partners (Wymer Jr and PhD 2003; Wymer Jr, Knowles et al. 2006). The set of activities required for sponsorship will be entirely 
different to that required for seeking a donation from a philanthropic source (Nowak and Washburn 2000; McGee and Donoghue 2009).

\section{Why sponsorship is not philanthropy}

Sponsorship of sports, arts, events and causes is now a mainstream marketing communications tool (Cornwell, Weeks et al. 2005; Simmons and Becker-Olsen 2006; Cornwell 2008). Sponsorship-linked marketing programme expenditure has continued to increase in recent times when compared to other forms of marketing communications. The total spending on sponsorship globally is expected to be US\$18.9 billion in 2012 which is an increase of $4.1 \%$ on the total for 2011 . About $40 \%$ of the total global amount is attributed to the North American region. According to IEG (2012) investment in sponsorship has grown at a higher rate for the past 20 years than both advertising and sales promotion. Despite this growth in expenditure it is only in relatively recent years (Walliser 2003; Thompson and Speed 2007) that academic research on sponsorship has reflected similar growth. The aim of this article is to contribute to this growing body of sponsorship knowledge in the non-profit sector.

Sponsorship in its earliest form dates back to ancient Greece (McDonald 2000). Athletes in the original Olympic Games required the patronage of wealthy citizens in order to live while training and competing. In return patrons gained attention for their generosity and public spiritedness; a helpful advantage if running for public office. In many ways the same motivation drives commercial sponsorship today, that is the desire to be thought well of. Lardinoit and Quester (2001) repeat a common view held by researchers (see for example Cornwell 1995) when they observe that there is some confusion in the literature over what is an acceptable definition of sponsorship. Lardinoit and Quester suggest that there is, however, some consensus relating to the definition proposed by Meenaghan (1991): 
"Commercial sponsorship involves an investment in cash or kind in an activity, person or idea for the purpose of exploiting the potential associated with this activity." (p 36)

Cornwell and Maignan (1998) argue that sponsorship is more than just an association between a sponsor and a sponsee and includes all marketing and communication efforts undertaken by sponsors to leverage their investment in the sponsored activity or event. They prefer to use the broader definition first proposed by Cornwell (1995) who defined sponsorship-linked marketing as:

"The orchestration and implementation of marketing activities for the purpose of building and communicating an association (link) to a sponsorship...” (pp 15-16)

The marketing of the sponsorship relationship is deemed to be necessary if the sponsorship fee is to be a worthwhile investment (Chien, Cornwell et al. 2011). Further benefit can be gained by leveraging the sponsorship through promotion tools such as corporate hospitality (Sylvestre and Moutinho 2007). Cliffe and Motion (2005) highlight that sponsorship associations and experiences can be an effective tool in brand management. However, the link between the sponsor's brand and the event or cause being sponsored requires careful consideration to ensure that a congruency between the two entities that can be exploited (Olson and Thjømøe 2011).

It becomes clear that sponsorship is more than patronage; it involves the exchange of a fee for association rights between a sponsor and a sponsee, and includes the marketing of that association by the sponsor. There is also the added dimension of actual recipient of the benefits of sponsorship, especially in the field of sports (Thompson and Speed 2007). It is widely agreed that sponsorship can positively affect consumer attitudes towards the attributes of a brand (Chien, Cornwell et al. 2011). Sponsorship should be distinguished from sports 
marketing, event marketing and cause-related marketing; all of which may include sponsorship as an element in their marketing communication mix, but equally, may exclude sponsorship from that mix (Thompson and Speed 2007). Sponsorship should also not be construed as a form of advertising, although sponsorship of television and radio programs can build brand awareness and image for the sponsor (through media exposure) in a manner analogous to advertising. However, as Yeshin (1998) notes, "here the objective is to derive benefit from the association of the (brand) name and a program which has relevance to a desired target audience" ( $\mathrm{p}$ 273). Whereas advertising seeks to persuade directly, sponsorship seeks to persuade indirectly; by association. Sponsorship, then, is an independent, legitimate constituent in current marketing communications industry (Farrelly, Quester et al. 2006; Chien, Cornwell et al. 2011; Olson and Thjømøe 2011).

However, sponsorship is not a philanthropic act. Sponsorship implies that there will be:

- a return on investment for the sponsoring organization

- a financial or other measureable benefit for the organization (e.g. higher volumes of product sales)

- a marketing outcome (e.g. greater levels of brand equity)

Philanthropy serves a different purpose; that of being seen to be responsible and of communicating to a variety of constituents regarding the 'goodness' of the organization (Porter and Kramer 2002). In this context, there is no expectation of a marketing or otherwise profitable outcome. Philanthropy is seen as a donation whereas sponsorship is an investment (Porter 2006).

Raising corporate sponsorship requires an understanding of the business decisionmaking process 
Corporate sponsorship requires a return-on-investment. Therefore, the raising of such sponsorship will need to consider what the 'return' is that can be exchanged for any given investment. Furthermore, as in any exchange process, there is a need to consider the business decision-making process to ensure that there is a potential for the 'buyer' to choose your 'product' rather than a competitor's product.

Before discussing possible returns, the decision making process from a purchase decision perspective requires consideration. A possible guide is the framework that originally put forward by Webster and Wind (1972). This framework proposed a number of stages and influences on business decision-making, in particular the impact of buying centre on buying behaviour. The fact that this is a group decision rather than an individual decision will mean that generic fundraising strategies will be insufficient. The motivation of one person in the centre cannot be inferred to be the same for all persons. Subsequent research (Khan and Schroder 2009; Sheth, Sharma et al. 2009; Dario 2011) has demonstrated that this fundamental premise has not changed; the alignment of individual motivations with the organizations goals is a first step in successful selling to an organizational buyer.

For organizational buying situations, Hutt and Speh (1995) describe an eight stage process (see Table 1). It should be note that this model describes a complex decision making mode, which is not always the case, especially with small-scale grants and sponsorships. These which may be routinised decision making and therefore be considered to be commensurate with modified or straight rebuy situations (Tsiros, Ross et al. 2009).

Table1: about here 
Probably the most important part of this staged process for the NPO is the setting of criteria for evaluating the potential sponsorship proposals. At this stage the NPO needs to be considered as being able to offer their involvement in sponsorship as a possible solution to a particular business problem. NPOs seeking sponsorship therefore have to be deeply concerned about the types of business problem that can be addressed by sponsorship arrangements.

\section{What are the motivations of sponsors when seeking sponsorship?}

Sponsorship is often framed as a solution to a marketing problem. As a consequence, much of the sponsorship literature contains references to providing brand support and building brand equity (Cliffe and Motion 2005; Cornwell, Weeks et al. 2005; Bibby 2006; Simmons and Becker-Olsen 2006; Bibby 2011; Chien, Cornwell et al. 2011). In addition, a large amount of research revolves around sports sponsorship (cf. Sparks 1997; Farrelly and Quester 2003; Zhang, Bennett et al. 2003; Neale and Funk 2006; Lings and Owen 2007; Quester 2007). To guide this study we returned to the seminal article by Meenaghan (1983) who proposed the following set of objectives for sponsoring organizations (Table 2).

\section{Table 2: about here}

Specifically, the aim of this research was to develop an understanding of sponsorship of NPOs from a behavioural perspective. The study sought a deeper understanding of the corporate decision making that was involved in establishing a sponsorship partnership with a NPO. The assumption being that the behaviours within this process would have similarities to other B2B partnership formations. 


\section{Methodology}

Data for this study were collected from 30 participants through a series of semi-structured indepth interviews regarding their organization's behaviors with regard to establishing sponsorship agreements with nonprofit organizations. The top 100 companies who expressed an interest in corporate social responsibility by identifying this interest in their annual reports, were selected from the Australian Stock Exchange list. As their interest in supporting 'socially responsible' activities was expressed publicly, it was inferred that they might also be more likely to be involved in sponsorships. From this pool of potential research participants, 50 organisations were initially contacted about the study by telephone, and 30 people agreed to be interviewed. The interviewees were all at senior levels of the marketing and corporate communications functions within their respective organisations. Each of the participants had responsibility for sponsorship and/or corporate social responsibility activities. The semistructured interviews varied in length from half an hour to one and a half hours, depending on their willingness and ability to describe the sponsorship behaviours adopted by their organizations. During in-depth interviews participants were invited to discuss the types of sponsorship and the processes which were used to establish sponsorship relationships or partnerships (the terms were used interchangeably). The context was that of sponsoring nonprofit organizations. While many organizations also undertook commercial sponsorship activities, the focus was on the nonprofit sector.

The interviews were transcribed and analyzed using a holistic (contextualizing) method. This method of analysis requires that the analyst(s) reads the whole data set and develop a set of descriptions of the situation (context) using the material (Tashakkori and Teddlie 2009). While it sometimes involves counting, it does not purport to be a quantitative form of analysis as the intent is to provide evidence for the existence of some phenomenon. The purpose is to identify major problems, test plausibility and provide indicators for priorities for 
the researcher in any subsequent analysis (Drass 1980). As the purpose of this research was to identify potentially effective processes for NPOs to establish sponsorship relationships, this method is considered sufficient for this essentially exploratory research.

\section{Results and discussion}

\section{Motivations for undertaking sponsorship}

The results can be grouped into five main areas. The first of these are the motivations for undertaking sponsorship and these were similar to those identified by Meenaghan (1983). The most cited reason for participating in sponsorship was that of enhancing corporate stature which can be considered as meeting the sponsoring organizations 'broad corporate objectives' (Table 2, category 1). The terms used by respondents for this concept varied from 'good corporate citizenship', 'good PR value' and 'good community participation' to 'corporate social responsibility' and 'corporate accountability'. The more cynical participants used the term 'good PR value', implying that there was limited 'real' (meaning dollar) value in the sponsorship. Again, there was no effectiveness measurement associated with this objective for sponsoring. However, it was the most important reason given for sponsorship of the NPO. Sponsorship of the NPO was 'being seen to be good' rather than having any expected return. As such, it might be considered to be commensurate with the philanthropic act described earlier. However, a word of caution for eager NPOs is required at this point: corporate sponsorship is paid from a different funding source than philanthropy.

Another major objective of sponsorship identified in this category was to pre-empt any potential negative publicity that might flow from organizational activities. This was particularly important in high-risk industries such as mining and the major drug companies. The most likely sponsorship in these cases would be of events and causes that would provide the organization with counteractive publicity effects in case of crisis. As a consequence, these 
objectives were not measured (most people had not actually had a crisis of sufficient magnitude to test the effects). For NPOs seeking sponsorship the closer their cause to a potential negative event, the more likely the ability to establish a sponsorship partnership the relationship becomes a form of public relations insurance.

A final objective that can be included in this category relate to the sponsorships whereby NPOs are used to assist in improving employee morale. Organizations are increasingly putting together programs of sponsorship involving employees in sponsorship activities (Pajo and Lee 2011). While these connections make 'sense' from a corporate social responsibility perspective, it is not clear if a small NPO, with limited public visibility, would be able to provide sufficient value to attract a major sponsorship. Small sponsorships related to employee morale tended to go to local sporting clubs and grass roots activities closely related to the brand values of the organization (and possibly more importantly to activities that the employees were personally involved in).

Product related motivation (Table 2, category 2) was another objective of sponsorship raised by participants. Many freely admitted that they used sponsorship to gain access to distribution channels that would not otherwise be available. The main thrust of this type of sponsorship is to not only sponsor a specific event but to also provide merchandise at the event.

Sales objectives (category 3) were also discussed by participants. Interestingly, while other research demonstrates that sales performance is no longer a major expectation from sponsorship (Cousens, Babiak et al. 2006), seven of the 30 participants indicated that eventual sales performance was sought from the sponsorship. That is, while they recognized that the link between sponsorship and sales was tenuous in terms of direct measurement, they were still expecting that sponsorship would provide sales in the long run. None of the companies attempted to measure sales as a result of sponsorship performance. 
Corporates become involved in sponsorships to achieve media coverage (Table 2, category 4). Sponsorship was seen by participating organizations as a very cost effective form of promotion. If the event is taken up by the media then it can gain substantial advertising through prime time news forecasts, magazines, and newspapers. In this way, the sponsorship would gain an increase in public awareness for the corporation and its products. However, for the NPO, unless they have significant market presence and a large supporter base, none of these objectives are likely to be relevant to the potential partnership, as the NPO would not be able to assist in the achievement of such goals.

A fifth category involves the provision of hospitality to influence those guests targeted for inclusion. One factor that appears to be a by-product of sponsorship but is becoming increasingly important to the corporate sponsor is the access to hospitality facilities especially when linked with other forms of marketing promotion (Sylvestre and Moutinho 2007). These facilities include corporate boxes at the football or the tennis, and tickets to events for sponsors to give to major clients and suppliers. The point of these facilities is to show that the companies are involved in sponsorship and to provide entertainment facilities for clients and senior staff. It is seen as one way of differentiating yourself from your competitors and being able to enjoy yourself at the same time. However, as the hospitality is linked strongly to business and sales expectations, the NPO is unlikely to be able to provide sufficiently comfortable entertainment to their sponsors. There is a growing 'market' in the sponsorship of arts events (such as gallery exhibitions) rather than sponsoring the organization. This makes cash flow calculations difficult for the NPO. In addition, the NPO has to stage a major event and have it to some level of planning before they can make a sponsorship request. Importantly, the participants in this study did not believe that NPOs should be in the business of providing corporate hospitality, as it is not an efficient use of 
their funds and believed that it would be a waste of their money. This seems to be an important point of differentiation between the corporate and NPO sponsors.

The final category (Table 3) involved the objective of seeking personal satisfaction. While this was not specifically highlighted by the participants, it was implicit in their responses rather than specifically stated and should be noted for further investigation.

Importantly, there was a distinction made between cause related marketing, CSR and sponsorship. Cause related marketing was mostly associated with product marketing (for example see the Pink Ribbon campaign sponsors (Pink Ribbon corporate website, 2012) and its purpose was to increase sales (a concrete measurable objective). CSR's purpose was to improve reputation and image (abstract and unmeasured aims). Sponsorship was mostly used to improve brand image (product or service) concrete and measured objectives).

\section{Who is involved in making decisions regarding sponsorship?}

The second major finding is a consideration of who in the corporation makes the decision regarding sponsorship. This is of particular importance for NPOs who are seeking sponsorship. The buying centre or decision making unit evaluates the proposals and submissions in addition to determining the criteria for selection of the sponsees. As a consequence, understanding their needs is important. However, our research shows that very few NPOs are considering who to target within the sponsoring organization when they make a submission. Furthermore, while the buying centre must be an important component in decision making with regard to sponsorship decisions, it was somewhat difficult to ascertain who comprises the buying centre. However, in this research, depending on the dollar value of the sponsorship program and the complexity of the organizational decision making process, different position titles appeared as part of the decision making process (see Figure 1) . 
Figure : about here

In many cases, the decision was made by marketing managers, with reference to the CEO or the Board. The CEO, even if not personally involved in the decision, often used their power of veto in the decision-making. That is, unless the proposal assisted the agenda of the CEO, the submission might not even make to the board for consideration. For NPOs this is problematic; how does the NPO add value to an organization in a marketing sense? However, in philanthropic decision making situations, in larger organizations, it appears that a donations committee is usually formed from all the persons interested in the sponsorship decision. Some likely titles of these persons are presented in Table 3.

Table 3: about here

In the researched organizations there were set guidelines for group decision making; these include evaluation criteria; for example: Fit with Corporate Objectives, Opportunities for exposure, Target Audience, Type of benefit sought, type of commitment required, and value of sponsorship. However, extraordinary opportunities can bypass these guidelines; as can strong championship by a powerful member of the group. In these cases, the power in the group is not necessarily with the person with the best title, it will be with the person who has the best capacity to influence the other group members.

\section{Time involved in the sponsorship process.}

The third major area related to the time involved the lead time of sponsorship decisionmaking. The findings suggest that when establishing sponsorships NPOs are currently at a disadvantage. It would appear that NPOs are making submissions on an ad hoc basis rather than in a long-term strategic manner- that is seeking donations rather than partnerships or 
relationships that provide value in both directions. Large scale, long-standing commitments (usually commercial) take precedence over small requests. Furthermore, businesses plan financial commitments up to five years in advance (or more in the case of events such as the Olympics). NPOs need to adjust their cycles to ensure that sufficient time for decision making is allowed. It can take up to three years to create a submission and have it funded, if the commitment required is more than $\$ 100,000$ or the time frame for the sponsorship is longer than 12 months (Figure 1). The decision making time required depends on the amount of money being sought for the sponsorship, the amount of time before the event and the number of people involved in the decision.

\section{Locus of sponsorship decisions.}

In this research, there was a growing trend towards decentralisation of the sponsorship decisions. That is, the larger multinational organizations are leaving the decisions about the sponsorship to the local office level. For NPOs, this presents opportunities as the decision making can be localised. However in the main, the amount of sponsorship 'allowed' was contingent on objectives handed down from head office. Hence, local decisions could be made about who was sponsored, but not about the dollar value of the sponsorship. As a consequence, NPOs need to be aware of the amount of autonomy in decision-making that is allowed at the local level before spending the effort of preparing a submission. Importantly, it appears that cases can be made for exceeding any budget so the local offices do have some autonomy in the process, but it may take longer as the negotiations with head office take place.

There are a number of reasons that organizations choose not to sponsor NPOs. These are: 1 . They have no method of assessing the value of the sponsorship. 2. The events/activities have ill defined audiences both in terms of numbers and demographics. 3. There is a lack of 
coordination within the organizations so that possible events are not filtered through to those people in a position to make a decision. 4 . There is a duplication of responsibility between head office and local branch organizational networks. 5. There is a lack of understanding on behalf of the seekers of sponsorship of the needs of the sponsors and of the benefits of sponsorship to the sponsor. The implication of this for seekers of sponsorship is that they must carefully consider who they approach for sponsorship. NPOs must tailor their approach to each individual company and help the organization to evaluate the activity in terms of what it will do for them. It is not self evident to a potential sponsor why they should sponsor a particular NPO. It is a marketing problem for the seekers of sponsorship to decide who to ask for sponsorship, the same as it is for the sponsors to decide who they should sponsor.

\section{Types of sponsorships.}

There are various types of sponsorship being undertaken. The first type is on a localised and relatively small scale. This type of sponsorship is primarily pursued by smaller organizations and consists of donations to local charities and events. For example, a clothing manufacturer may be donating excess or end-of-season stock to the local school fete. Sometimes these donations will also include cash, but the cash component is variable and not reliable. To the sponsor, the purpose of this sponsorship is not to raise public awareness or to gain notoriety as a good citizen. Its purpose can be best understood by looking at the concept of exchange. The sponsor in this case is exchanging something they do not value highly (excess stock) for something they do (feeling good about themselves). Sponsorship at this level is perhaps not truly a corporate decision as it is mainly the managing director's decision to be involved in sponsorship. Therefore it is an individual decision as opposed to a group decision as is the norm in an industrial environment. 
The second type of sponsorship of goods and/or services and can be undertaken by all types of organizations. This type of sponsorship is not limited to the mainly small companies described in level one. Large companies also participate at this level; however, the recognition required in exchange for the goods and services tends to vary in proportion to the size of the organization. A small company is contented with small local advertising and exposure; a large company requires a wider scope in their communications messages. For larger companies there is also an element of risk in being involved with a charity. Firstly, the charity or cause may be the 'wrong' one for the various publics of the organization.

Secondly, it can encourage other charities to seek sponsorship. The fact that it is goods and/or services and expertise that are being donated lessens the apparent cost of the exchange for the sponsor. The exchange of already produced goods is of lesser value to the sponsor than the exchange of the cash it might take to buy the equivalent amount of goodwill with traditional communications methods.

The third type of sponsorship is generally undertaken by the larger organizations that are seeking specific events or causes that will enable them to increase public awareness of their company or products. These organizations treat sponsorship as a marketing communications tool as any other and therefore sponsorship arrangement has to comply with communications objectives and fit within the overall marketing strategy.

\section{Conclusion}

Overall, it would appear that the term 'sponsorship' implies a set of commercial activities that may not be a comfortable fit with mission-led non-profit organizations (Meenaghan 1991; Nowak \& Washburn 2000). These commercial activities require relationship management strategies, a profit focus and an ability to adapt systems to meet the needs of the sponsor. Furthermore, there is a specialised set of skills required from the NPO when it comes to adding value in a sponsorship process. The foremost of these skills is an 
understanding of marketing ROI and associated metrics. Secondly, is that a professional sales management approach to revenue-raising is quite different to that of fundraising (McGee \& Donoghue, 2009). Fundraising is an important function for the NPO but it is applicable at the 'business to consumer' level. On the other hand, sales management is about establishing long term relationships at a 'business to business' level. There may be a contradiction between the objectives of an individual and those of an organisation which may be answerable to shareholders.

However, while the term sponsorship has commercial connotations, in this research, it was reasonably clear that corporate social responsibility was not considered sponsorship although the terms are often used interchangeably by those not actively involved in sponsorship decisions. CSR has its own set of connotations (Carroll, 1999) and commercial outcomes were not paramount in that context. Again, this presents difficulties for the NPO who must attempt to find the right location for their request: Public affairs (CSR) or Marketing (Sponsorship), and risk rejection because their request was inappropriately directed.

Other conclusions have direct implications for NPO management. The complexity of decision-making is also problematic for resource-restrained NPOs seeking revenue for the longer term. As it can take more than a year to seek potential sponsors, persuade them about the outcomes and develop a relationship, NPO managers need to ensure that they can cover their short-term. As was highlighted in this study, they also need to identify the locus of the decision-making. Additionally, how do they find the influencers who will facilitate the application through the processes and also how do you find out about the processes? Some strategic insight into business decision-making would be useful for the NPOs and if this is not available to them 'in house' it may be of strategic importance in the quest towards a attracting an valuable sponsorship partnership. 


\section{References}

Bibby, D. (2006). adidas's sponsorship of the New Zealand All Blacks: The relationship between brand image and brand equity in sports sponsorship. School of Applied Communication. Melbourne Australia, RMIT University. Masters: 135.

Bibby, D. N. (2011). "Sponsorship portfolio as brand image creation strategies: A commentary essay." Journal of Business Research 64(6): 628-630.

Carroll, A., (1999) "Corporate Social Responsibility: Evolution of a definitional Construct." Business \& Society 38(3): 268-295.

Chien, P. M., T. B. Cornwell, et al. (2011). "Sponsorship portfolio as a brand-image creation strategy." Journal of Business Research 64(2): 142-149.

Cliffe, S. J. and J. Motion (2005). "Building contemporary brands: a sponsorship-based strategy." Journal of Business Research 58(8): 1068-1077.

Cornwell, T. B. (1995). A sponsorship-linked marketing research agenda. Academy of Marketing Science.

Cornwell, T. B. (2008). "State and the art and science in sponsorship-linked marketing." Journal of Advertising 37(3): 41-55.

Cornwell, T. B. and I. Maignan (1998). "An International Review of Sponsorship Research." Journal of Advertising 27(1): 1-21.

Cornwell, T. B., C. S. Weeks, et al. (2005). "Sponsorship-linked marketing: Opening the black box." Journal of Advertising 34(2): 21-42.

Cousens, L., K. Babiak, et al. (2006). "Beyond Sponsorship: Re-Framing Corporate-Sport Relationships." Sport Management Review 9(1): 1-23.

Dario, M. (2011). "Organizational buying effectiveness in supply chain context: Conceptualization and empirical assessment." Journal of Purchasing and Supply Management 17(4): 246-255.

Drass, K. A. (1980). "The analysis of qualitative data: A computer program." Journal of Contemporary Ethnography 9(3): 332-353.

Farrelly, F. and P. Quester (2003). "The effects of market orientation on trust and commitment: The case of the sponsorship business-to-business relationship." European Journal of Marketing 37: 530-553.

Farrelly, F., P. Quester, et al. (2006). "Changes in sponsorship value: Competencies and capabilities of successful sponsorship relationships." Industrial Marketing Management 35(8): 1016-1026.

Hutt, M. D. and T. W. Speh (1995). Business marketing management: a strategic view of business and organisational markets. Fort Worth Tx, Dryden Press.

IEG (2011). IEG Sponsorship report. Chigago, IEG www.sponsorship.com.

IEG (2012). IEG Sponsorship Report. Chicago. IEG www.sponsorship.com.

Khan, S. and B. Schroder (2009). "Use of rules in decision-making in government outsourcing." Industrial Marketing Management 38(4): 379-386.

Lardinoit, T. and P. Quester (2001). "Attitudinal effects of combined sponsorship and sponsor's prominence on basketball in Europe." Journal of Advertising Research January/February: 1-13.

Lings, I. N. and K. M. Owen (2007). "Buying a sponsor's brand: the role of affective commitment to the sponsored team." Journal of Marketing Management 23: 483-496.

McDonald, C. (2000). Sponsorship. WARC Best Practice (April). World Advertising Research Council. London UK, WARC. 
McGee, S. and F. Donoghue (2009). "The Conundrum of Fundraising in Nonprofit Organizations: A Story from Ireland." Journal of Nonprofit \& Public Sector Marketing 21(4): 367-383.

Meenaghan, J. A. (1983). "Commercial sponsorship." European Journal of Marketing 17(7): 5-73.

Meenaghan, T. (1991). "The role of sponsorship in the marketing communications mix." International Journal of Advertising 10(1): 35-47.

Mullen, J. (1999). "Hoping to Enhance a Local Funding Relationship: Exploring Private Sector Business Preferences When Contributing to Nonprofit Organizations." Journal of Nonprofit \& Public Sector Marketing 6(4): 87-99.

Neale, L. and D. Funk (2006). "Investigating motivation, attitudinal loyalty and attendance behaviour with fans of Australian Football." International Journal of Sports Marketing and Sponsorship 7(4): 307-317.

Nowak, L. I. and J. H. Washburn (2000). "Marketing alliances between non-profits and businesses: Changing the public's attitudes and intentions towards the cause." Journal of Nonprofit \& Public Sector Marketing 7(4): 33-44.

Olson, E. L. and H. M. ThjØmØe (2011). "Explaining and articulating the fit construct in sponsorship." Journal of Advertising 40(1): 57-70.

Pajo, K. and L. Lee (2011). "Corporate-Sponsored Volunteering: A Work Design Perspective." Journal of Business Ethics 99(3): 467-482.

Peloza, J. and D. N. Hassay (2008). "Make versus Buy Philanthropy: Managing Firm-Cause Relationships for Strategic and Social Benefit." Journal of Nonprofit \& Public Sector Marketing 19(2): 69-90.

"Pink Ribbon Day." (2012). http://www.pinkribbonday.com.au/content/corporate-partners. Accessed 14/2/12.

Porter, M. (2006). Corporate Philanthropy: Taking the high ground. http://earthmind.net/ngo/docs/philanthropy-high-ground.pdf, Foundation Strategy Group.

Porter, M. E. and M. R. Kramer (2002). "The competitive advantage of corporate philanthropy." Harvard Business Review(December): 5-16.

Quester, P. (2007). Sport Marketing and Sponsorship: I cheer therefore I am? Actes du XXIIIème Congrès International de l'AFM - 31 mai \& 1er juin 2007, Aix-les-Bains.

Runte, M., D. Z. Basil, et al. (2009). "Cause-Related Marketing from the Nonprofit's Perspective: Classifying Goals and Experienced Outcomes." Journal of Nonprofit \& Public Sector Marketing 21(3): 255-270.

Sheth, J. N., A. Sharma, et al. (2009). "Why integrating purchasing with marketing is both inevitable and beneficial." Industrial Marketing Management 38(8): 865-871.

Simmons, C. J. and K. L. Becker-Olsen (2006). "Achieving Marketing Objectives Through Social Sponsorships." Journal of Marketing 70(4): 154-169.

Sparks, R. (1997). "Tobacco-control Legislation Public Health and Sport Sponsorship." AsiaAustralia Marketing Journal 5(1): 59.

Sylvestre, C. M. and L. Moutinho (2007). "Leveraging Associations: The Promotion of Cultural Sponsorships." Journal of Promotion Management 13(3/4): 281-303.

Tashakkori, A. and C. Teddlie (2009). Foundations of Mixed Methods Research. Thousand Oaks, CA, Sage Publications.

Thompson, P. and R. Speed (2007). A typology of sports sponsorship activity. International perspectives on the management of sport. M. Parent and T. Slack. United States of America, Elsevier: 247-267.

Tsiros, M., W. T. Ross, Jr., et al. (2009). "How Commitment Influences the Termination of B2B Exchange Relationships." Journal of Service Research 11(3): 263-276. 
Walliser, B. (2003). "An international review of sponsorship research: Extension and update." International Journal of Advertising 22(1): 1-27.

Webster, F. E. and Y. Wind (1972). "A general model for understanding organizational buying behaviour." Journal of Marketing 36(April): 12-19.

Wymer Jr, W. W., P. Knowles, et al. (2006). Nonprofit marketing : marketing management for charitable and nongovernmental organizations Thousand Oaks, Ca, Sage.

Wymer Jr, W. W. and S. S. PhD (2003). "Dimensions of business and nonprofit collaborative relationships." Journal of Nonprofit \& Public Sector Marketing 11(1): 3-22.

Yeshin, T. (1998). Integrated marketing communications: The holistic approach. Oxford UK, Butterworth-Heinemann.

Zhang, J., G. Bennett, et al. (2003). "Generation Y's Perceptions of the Action Sports Industry Segment." Journal of Sport Management 17(2): 95-115. 
Tables and Figure

Table 1: Commercial Buying process with Implications for sponsorship*

\begin{tabular}{|c|c|c|}
\hline & Stage & Description \\
\hline 1 & $\begin{array}{l}\text { Anticipation or recognition of a } \\
\text { need. }\end{array}$ & $\begin{array}{l}\text { Awareness that a business problem exists and } \\
\text { that there is a potential solution (which may be } \\
\text { sponsorship). }\end{array}$ \\
\hline 2 & $\begin{array}{l}\text { Determine characteristics of the } \\
\text { item required. }\end{array}$ & $\begin{array}{l}\text { The sponsoring organization decides their } \\
\text { objectives and strategies and determines } \\
\text { whether or not they will be involved in } \\
\text { sponsorship. }\end{array}$ \\
\hline 3 & $\begin{array}{l}\text { Description of the characteristics } \\
\text { of the items required. }\end{array}$ & $\begin{array}{l}\text { In sponsorship situations, this will normally be a } \\
\text { formal written plan with set objectives and a list } \\
\text { of possible partners. This stage will determine } \\
\text { whether or not sponsorship is considered as a } \\
\text { potential solution; and sets the criteria against } \\
\text { which future submissions and proposals will be } \\
\text { considered. }\end{array}$ \\
\hline 4 & $\begin{array}{l}\text { Search for an evaluation of } \\
\text { alternatives. }\end{array}$ & $\begin{array}{l}\text { Having determined what will satisfy the } \\
\text { objectives and the guidelines for sponsoring are; } \\
\text { the organization will then evaluate the } \\
\text { alternatives that are available. For example, } \\
\text { marketing, advertising, corporate } \\
\text { communications, publicity seeking and public } \\
\text { relations each have dimensions that can add } \\
\text { value to an organizational brand. In sponsorship } \\
\text { situations, at this stage there will be a shorter list } \\
\text { of potential partners. }\end{array}$ \\
\hline 5 & $\begin{array}{l}\text { Acquisition and analysis of } \\
\text { proposals. }\end{array}$ & $\begin{array}{l}\text { This stage is usually a call for tenders or other } \\
\text { sales applications. These proposals are usually } \\
\text { considered against some type of criteria (set in } \\
\text { earlier phases of the process). }\end{array}$ \\
\hline 6 & $\begin{array}{l}\text { Evaluation of proposals and } \\
\text { selection of suppliers. }\end{array}$ & $\begin{array}{l}\text { This stage may consist of reviewing the } \\
\text { proposals (submissions) that are put to them or } \\
\text { it may simply be renewing last year's } \\
\text { commitments. }\end{array}$ \\
\hline 7 & Selection of an order routine. & $\begin{array}{l}\text { At this stage the sponsor and the NPO negotiate } \\
\text { the best method of receiving the proposed } \\
\text { sponsorship. That is, will it be monetary or will } \\
\text { it be goods or expertise of services. This can be } \\
\text { a vital stage in the process in as much if things } \\
\text { are not clearly laid out; the NPO can find itself } \\
\text { without actual funds simply because they forgot } \\
\text { to ask for them in a manner which could be } \\
\text { managed by the sponsoring organization. }\end{array}$ \\
\hline
\end{tabular}




\begin{tabular}{|l|l|l|}
\hline & Stage & Description \\
\hline 8 & $\begin{array}{l}\text { Performance feedback and } \\
\text { evaluation. }\end{array}$ & $\begin{array}{l}\text { During this phase the organization evaluates the } \\
\text { success or otherwise of the investment and } \\
\text { calculates ROI and value. }\end{array}$ \\
\hline
\end{tabular}

* Based on Hutt and Speh's 8 stages of buying and implications for sponsorship seekers. Hutt, M. D. and T. W. Speh (1995). Business marketing management: a strategic view of business and organisational markets. Fort Worth Tx, Dryden Press.

Table 2: Summary of categories of objectives in sponsorship*

\begin{tabular}{|c|c|}
\hline \multirow{5}{*}{$\begin{array}{l}\text { 1. Broad Corporate Objectives } \\
\text { - } \quad \text { Community involvement } \\
\text { - } \quad \text { Increase the public awareness of } \\
\text { - } \quad \text { Alter public perception of the } \\
\text { company } \\
\text { - } \quad \text { Build goodwill among opinion- } \\
\text { - } \quad \text { Reassure policy holders and } \\
\text { - } \quad \text { Stockholders } \\
\text { - } \quad \text { An aid to staff relations } \\
\text { - } \quad \text { An aid to staff recruitment } \\
\text { - } \quad \text { Identify with a particular market } \\
\text { - } \quad \text { Facilitate prospecting for the sales } \\
\quad \text { people }\end{array}$} & 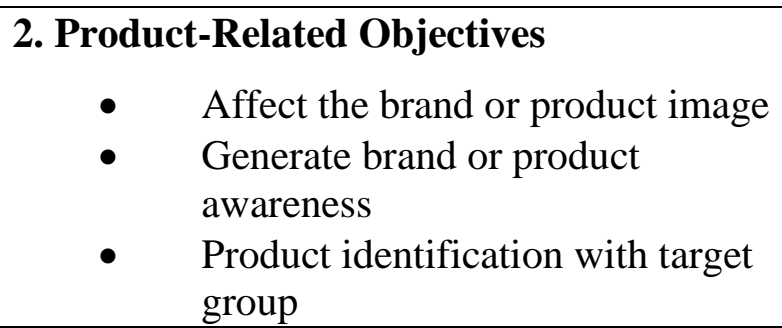 \\
\hline & $\begin{array}{l}\text { 3. Sales objectives } \\
\text { - Increase short-term sales } \\
\text { - Increase long term sales }\end{array}$ \\
\hline & $\begin{array}{l}\text { 4. Achieve Media Coverage } \\
\qquad \begin{array}{l}\text { Build product/company } \\
\text { awareness }\end{array}\end{array}$ \\
\hline & $\begin{array}{l}\text { 5. Guest Hospitality } \\
\text { • } \quad \text { Influence invited guests } \\
\text { • } \quad \text { Entertain invited guests }\end{array}$ \\
\hline & $\begin{array}{l}\text { 6. Personal Objectives } \\
\text { • Deliver personal satisfaction }\end{array}$ \\
\hline
\end{tabular}

*Based on the work of Meenaghan, J. A. (1983). "Commercial sponsorship." European Journal of Marketing 17(7): 5-73. 
Figure 1. Influence of dollar value and time involved in sponsorship decision-making.

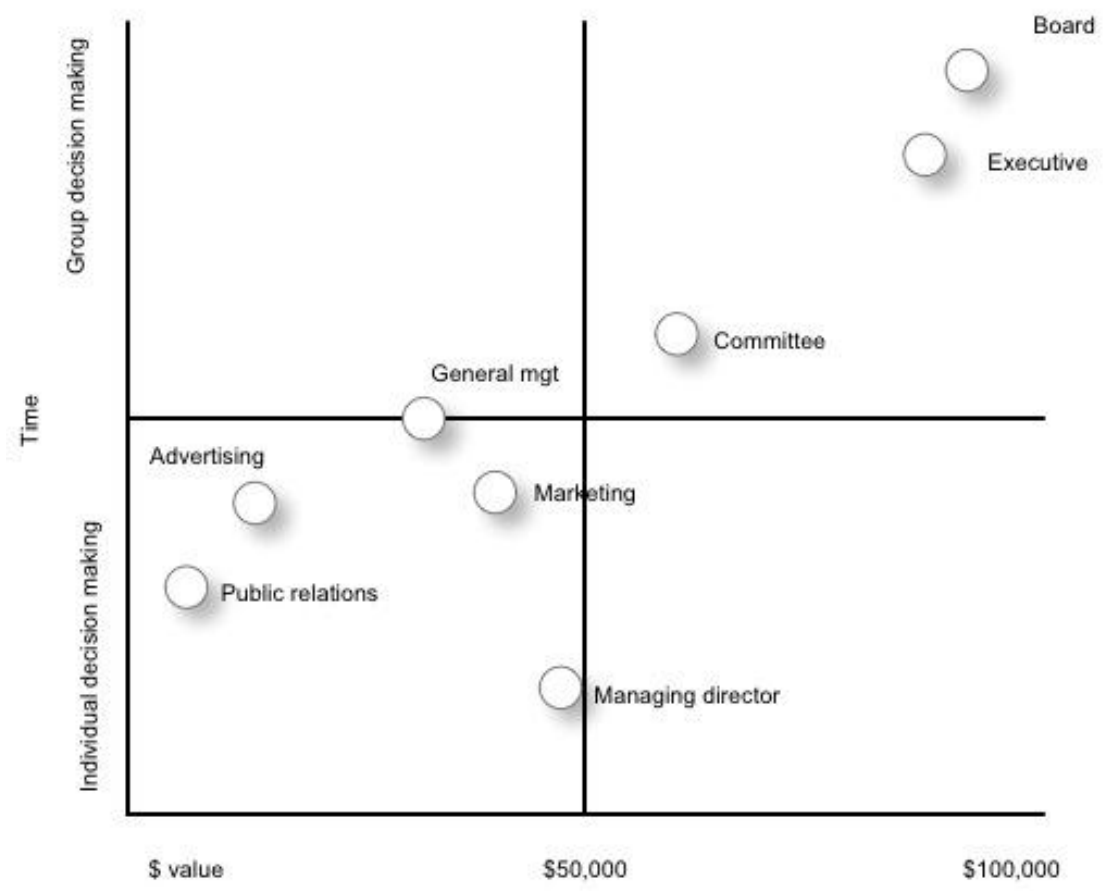

Table 3: The buying centre

Titles of personnel involved in decision making regarding sponsorship and philanthropy

\begin{tabular}{|l|l|l|}
\hline Public Relations Manager & Managing Director & General Manager \\
\hline Vice President - Marketing & Media Manager & Advertising Manager \\
\hline Marketing Manager & Marketing Director & Corporate Affairs Manager \\
\hline $\begin{array}{l}\text { Community Relations } \\
\text { Manager }\end{array}$ & Finance Director & General Manager - Finance \\
\hline
\end{tabular}

